\title{
The Determinants of Income of Cottage, Micro and Small Scale Enterprises in Jigawa State, Nigeria
}

\author{
Bello Malam Sa'idu, Muhammad Muazu Yusuf, and Ibrahim Muhammad Adam
}

\begin{abstract}
This paper investigates the determinants of income of cottage, micro and small scale enterprises $\left(\mathrm{CMSSE}_{\mathrm{S}}\right)$ in Jigawa State of Nigeria. The research used primary data collected from 300 enterprises drawn from three locations base on stratified random sampling technique. To analysed the data, we used multivariate regression model. The result shows positive relationship between income of the enterprises and education, experience, government support, gender and finance. The policy implication of the study is that policy makers should continue to formulate policies that will support $\mathrm{CMSSE}_{\mathrm{S}}$ financially in Jigawa State and the country at large.
\end{abstract}

Index Terms - Cottage, enterprises, finance, income, Micro, small scale.

\section{INTRODUCTION}

The Small and Medium Scale Enterprises (SMEs) are believed to be the engine room for the development of any economy in the World. The World super powers and fast growing economies, such as; the Asian Tigers and BRICS (Brazil, Russia, India, China, and South Africa) rely heavily on the growth and development of their cottage, micro, small and medium sized enterprises which enable them to attain technological superiority through motivation, imitation and innovation. They were able to further advance these industries or enterprises for increased productivity, incomes, employment and exports thereby achieving sustainable economic growth and development. The success of SMEs in countries of South Asia is a very good example of the importance of SMEs to the incomes and employment potentialities of such economies. Some of these Asian countries like; Malaysia, Taiwan, Thailand, Indonesia and Singapore whose economies were in shambles in the past, are now among the fastest growing economies in the World because of their viable SMEs. In a study, [1] noted that SMEs occupy $60 \%$ to $80 \%$ of the global economy, accounted for $98 \%$ of all private companies in the global market, contribute not less than $30 \%$ of the global Gross Domestic Product (GDP) and are responsible for $50 \%$ of the global labour force.

Generally, Nigeria is richly endowed with abundant human and natural resources which can transform cottage, micro and small scale enterprises or industries to modern industries especially in the northern part of the country. These resources are capable of boosting investment viability of Jigawa state

Manuscript received March 2, 2015; revised June 7, 2015.

The authors are with the Department of Economics \& Development Studies, Federal University Dutse, Jigawa State, Nigeria (e-mail: bellomalamali@gmail.com, ibraheemabulele@yahoo.com). and putting the state on the World map as a major exporter of the products of these industries to Europe, USA, Middle East, Asia and the Caribbean's. This could boost the GDP, help in correcting Balance of Payment disequilibrium and improve the well-being of the citizens of the state in particular and Nigeria in general.

The objectives of this research are; to assess the income potentials of cottage, micro and small scale enterprises (CMSSEs) in the state; to identify and examine factors that determine income potentials of CMSSEs.

\section{LITERATURE REVIEW}

There is no universally accepted definition of Cottage, Micro and Small Scale Enterprises. The definition depends on the context of the usage and it varies from country to country. In the discussion of informal sector, [2] noted that there is no single, uniformly acceptable, definition or classification of small-scale industries. However, the three major parameters generally considered in part or whole by most countries and institutions are: capital investment, number of employees and turnover [3]. But essentially the whole concepts of cottage, micro and small scale industries are captured under the grouping 'Micro, Small and Medium Enterprises' (MSMEs) or simply SMEs. But most recently, the apex regulatory agency for SMEs in Nigeria which is known as Small and Medium Enterprises Development Agency of Nigeria (SMEDAN), [4] defined MSME as those enterprises with number of employees as follows: micro enterprise, 1-9; small enterprise, 10-49; and medium enterprise, 50-199. Thus, we adopt the definition of SMEDAN because of its significance, relevance to the context of this research and usage in Nigeria.

\section{A. Practical Gap}

The economy of Jigawa state is largely characterized by informal sector activities with agriculture as the major economic activity. Over $80 \%$ of the population is engaged in subsistence farming and animal husbandry. Trade and commerce are undertaken on small and medium scale, especially in agricultural goods, livestock and other consumer goods. Other informal sector activities include; blacksmithing, leather-works, tailoring services, auto repairs, metal works, carpentry, tanning, dyeing, food processing, and masonry among others (see [5], [6]). Informal sector contribution for Nigeria is currently estimated at $57.9 \%$ of GDP according to the United Nation [7]. It is also estimated that $60 \%$ of female workers in developing countries are in the informal sector [7]. Therefore, to investigate these informal sector activities is practical gap that warrant research to identify it contribution to the economy. Also, it is paucity of 
data and to spawn baseline data on Micro, Small and Medium Enterprises (MSMEs) in Nigeria that was the rationale for the joint survey by [4]. Hence, the need to fill this practical gap that will also cover 'cottage enterprises'. Therefore, the foregoing is practical gap that will contribute to knowledge and practice.

\section{B. Methodological Gap}

No work found in the literature to our knowledge that have used our exact empirical modeling and methodology, but similarity in one or two variables used were seen, e.g. [8]-[15], etc. Consequently, there is short of empirical modeling as regard to income potentials of CMSSEs and this methodological knowledge gap demands research.

\section{Empirical Gap}

In the empirical gap spheres; age of the entrepreneur, size of the enterprise, entrepreneurs' experience, level of training (education), government support and access to finance was considered from different works emanating from various countries. We shall consider the empirics in turn:

On the age of the entrepreneur, some researchers have found a positive relationship between the age of the entrepreneur and business success or failure, e.g. [9] found that individuals ranging from 25 to 44 years were the most active entrepreneurs. Also, [16] found a significant correlation between age of the entrepreneur and business success in Indonesia. In their research in western Germany, [10] found an inverse relationship between age and the decision to start a business, implying that age does not matter in starting a business.

Size of the firm is one of the important factors that determine enterprise income generation. Some studies indicate that cottage, small and medium enterprises are not likely to employ more than the large firms. In their work, [17] wrote that, larger firms in cottage, small and medium scale business grow faster than smaller ones due to their ability to employ skillful managers and workers and to acquire more efficient technology and facilities and get credit needed for expansion. In a related study, [11] noted that larger firms have more resources that could be used to conduct market research, acquire information more effectively, and get consultancy from professional advisors. These help enterprises greatly in their effort to expand and perform more effectively. Also, [18] identified three reasons why smaller firms failed to perform, viz: information opacity; most of the time owned and managed by the entrepreneur himself and there is no much legal requirement to regularly report financial information; and fewer assets to offer as collateral. Thus, failure rate among smaller firms tend to be higher than large firms.

Entrepreneurs with vast experience and training in managing business are more capable of finding ways to open a new business. In identifying and describing patterns of success and failure among small businesses, [12] concluded that business success or failure is dependent not only on the behavior of business owners or managers, but also on the economic and social behaviors of the environment in which these businesses operate. Also, they suggested that successful businesses were likely to be managed by owners who had previous experience managing private business along the

\section{same line.}

Education and skills are important tools needed to run CMSSEs. Therefore, for small businesses to operate well, entrepreneurs need to have a sound education that will help them acquire skills and management techniques to run a successful business. Researches show that majority of those who run Cottage, Small and Medium Enterprises are the ordinary people whose educational background is wanting. Hence, they may not be well equipped to carry out managerial routines for their enterprises [19]. Moreover, [20] suggested that entrepreneurs with more education and training are more likely to be successful in business. They are more likely to generate income and employment. Similarly, [21] revealed that entrepreneurship education increases the formation of new ventures, the likelihood of self-employment, possibility developing new products, and the probability of owning a high-technology business. They also discovered that entrepreneurship education of employees increases the sales growth rates of firms. In different works, [22] and [23] revealed that successful entrepreneurs have higher education levels compared to that of unsuccessful entrepreneurs.

Entrepreneur's training is viewed as an activity that could help cottage, small and medium enterprises to create value and successfully deal with competition and environmental challenges. According to [24] enterprises that use innovative training practices are more likely to report better financial performance than their competitors who lack such training. Similarly, [14] observed that, training helps cottage, small and medium enterprises to cope with the latest accounting systems, information technology, management concepts and production techniques. Also, [13] found that training facilitates SMEs expansion and enhances profitability, productivity and competitive advantage.

The goal of Government intervention and support for SMEs is to enhance their performance. Government financial support is expected to increase the performance of SMEs by increasing their profit, turnover and employment generation. This is because SMEs are viewed as an important engine for income and employment generation as well as economic growth. However, [25] pointed out that the impact of the use of credit from the Government credit scheme on the profitability of firms can be positive (under favorable conditions) or negative (when sales and profit margins are low). Moreover, [26] found that only $7 \%$ of the SMEs graduate into large companies after receiving government financial support.

The CMSSEs are influence in their performance due to limited access to finance, consequently affecting both income and employment generation. In a study, [8] found that finance is among the four factors out of 15 factors (considered in the research) that were significant predictors of success. Similarly, [15] wrote that there is significant positive relationship between SMEs financing and economic growth in Nigeria via investment level. But, [27] observed that maximizing of profit through credit financing might not hold for SMEs. This is because SMEs find it difficult to borrow from commercial banks for many reasons and when they are able to borrow, the cost of borrowing are usually higher than those of large firms due to their higher credit risk. Therefore, the relationship between credit and profitability of SMEs may 
be negative due to high interest rates in developing countries compared to the developed countries where interest rates are generally low. Therefore, the foregoing empirical gaps justify research of this nature.

\section{MATERIALS AND METHODS}

\section{A. Population and Sample Size}

The population for this study is the entire CMSSEs in Jigawa state, the state consist of 27 local government areas (LGAs) that are divided into 3 senatorial districts. The stratification was done base on the 3 senatorial districts and three LGAs were randomly selected from each district. Three hundred (300) questionnaires were distributed to the enterprises in three locations from the three senatorial districts of the state. The three locations are; Birnin-Kudu/Dutse LGAs; Hadeja LGA; and Gumel LGA. A structured questionnaire was developed for data collection. Questions were asked on the income, number of employees, size of the business, age of the entrepreneur, level of education of the entrepreneur and number of training attended by the entrepreneur among others.

The study employs descriptive statistics and multiple regression analyses. The regression is to test the relationship between income of the enterprises in the study and other variables that are expected to influence their ability to generate income, income of the responding enterprises is the dependent variable and age of the entrepreneur, experience of the entrepreneur, level of education of the entrepreneur, training at of the entrepreneur, size of the enterprise government support for the enterprise and finance are the independent variables.

\section{B. Empirical Model}

To test the income generation of the enterprises, the following model was estimated as:

$$
\begin{gathered}
\mathrm{INC}=\alpha+\beta_{1} \mathrm{EDU}+\beta_{2} \mathrm{EXP}+\beta_{3} \mathrm{AGE}+\beta_{4} \mathrm{TYP}+ \\
\beta_{5} \mathrm{GSP}+\beta_{6} \mathrm{GND}+\beta_{7} \mathrm{SLK}+\beta_{8} \mathrm{FIN}+\mathrm{e}
\end{gathered}
$$

where; INC = Income of the enterprise, EDU = Level of education of entrepreneur, EXP $=$ Experience of the entrepreneur, AGE $=$ Age of the entrepreneur, TYP $=$ Size of the enterprise, GSP = Government support for the enterprise, GND $=$ Sex of the entrepreneur, SLK $=$ Training of the entrepreneurs, FIN $=$ Source of finance of the enterprise, $e=$ Error term, $\alpha=$ Autonomous constant term, $\beta_{1}$ to $\beta_{7}=$ Parameters of the model.

\section{EMPIRICAL RESULTS}

The result is divided into two: the descriptive statistics that give an overview of the responding enterprises and entrepreneurs as well as the multivariate regression results.

\section{A. Descriptive Statistics}

The result indicates that more than $53 \%$ of the enterprises in the research are Cottage/Micro Enterprises as against about 47\% that are Small Scale Enterprises. This indicates that the number of Cottage/Micro enterprises is almost equal to the number of Small Scale enterprises in Jigawa state.

TABLE I: SIZE OF THE RESPONDING ENTERPRISES

\begin{tabular}{lcc}
\hline Response & Frequency & Percent \\
\hline Cottage/micro & 139 & 53 \\
Small & 124 & 47 \\
\hline Total & $\mathbf{2 6 3}$ & $\mathbf{1 0 0}$ \\
\hline Source: Authors computations & &
\end{tabular}

The result also indicates that more than $31 \%$ of the respondents attended Tertiary Education, 30.03\% attended Secondary Schools, $14.82 \%$ attended Primary Schools and surprisingly, only about $24 \%$ of the respondents have no formal Education. It is surprising cottage micro and small scale businesses are small and informal enterprises that are expected to be dominated by people with no or less formal education (see Table II).

TABLE II: EDUCATIONAL QUALIFICATION OF THE RESPONDENTS

\begin{tabular}{lcc}
\hline Response & Frequency & Percent \\
\hline No formal education & 63 & 23.95 \\
Primary education & 39 & 14.82 \\
Secondary education & 79 & 30.03 \\
Tertiary education & 82 & 31.18 \\
\hline Total & $\mathbf{2 6 3}$ & $\mathbf{1 0 0}$ \\
\hline
\end{tabular}

Source: Authors computations

Furthermore, the result also indicates that $21.29 \%$ of the of the respondents are between the age of 18 to $25,31.56 \%$ between the age of 26 to $35,23.19 \%$ are between the age of 36 to 45 , and only $19.29 \%$ have age above 45 years. Similarly, the result indicates that responding entrepreneurs spent an average of 9 years in the business (see Table III).

\begin{tabular}{lcc}
\multicolumn{3}{c}{ TABLE III: AGE OF THE RESPONDENTS } \\
\hline Response & Frequency & Percent \\
\hline $18-25$ & 56 & 21.29 \\
$26-35$ & 83 & 31.56 \\
$36-45$ & 61 & 23.19 \\
45 and above & 63 & 23.96 \\
\hline Total & $\mathbf{2 6 3}$ & $\mathbf{1 0 0}$ \\
\hline Source: Authors computations & &
\end{tabular}

Out of the 263 enterprises sampled, $94.68 \%$ were owned by males and the remaining $5.32 \%$ were owned by females. This clearly shows that in Jigawa state the CMSSEs sub-sector is

\begin{tabular}{|c|c|c|}
\hline Responses & Frequency & Percent \\
\hline Male & 249 & 94.68 \\
\hline Female & 14 & 5.32 \\
\hline Total & 263 & 100 \\
\hline
\end{tabular}
male dominated (see Table IV).

\begin{tabular}{lcc}
\multicolumn{3}{c}{ TABLE V: EXPERIENCE OF THE RESPONDENTS } \\
\hline Response & Frequency & Percent \\
\hline $1-5$ & 120 & 45.45 \\
$6-10$ & 59 & 22.53 \\
$11-20$ & 55 & 20.95 \\
$21-30$ & 25 & 9.49 \\
\hline 31 and above & 4 & 1.58 \\
\hline Total & $\mathbf{2 6 3}$ & $\mathbf{1 0 0}$ \\
\hline
\end{tabular}

Source: Authors computations

Furthermore, about $45.5 \%$ of the responding entrepreneurs have one to five years experience in the business, $22.5 \%$ had 6 
to 10 years experience, $20.9 \%$ had 11 to 20 years, $9.49 \%$ of the respondent had 21 to 30 years and $1.58 \%$ have spent 31 and over years in the business (see Table V).

Similarly the descriptive Statistics result shows that $24.47 \%$ of the respondents had a daily income less than $\mathrm{N} 1,000,21.94 \%$ had income between the intervals of N1,100 $-\mathrm{N} 2,000,17.72 \%$ had income between N2,100 - N3,000 and $9.7 \%$ also have income between, $\mathrm{N} 3,100-\mathrm{N} 4,000$ and $26.26 \%$, had a daily income of more than N4,100 (see Table VI).

TABLE VI: DAILY INCOME OF THE RESPONDENTS

\begin{tabular}{lcc}
\hline Response & Frequency & Percent \\
\hline Less than 1000 & 120 & 24.47 \\
$1100-2000$ & 59 & 21.92 \\
$2100-3000$ & 55 & 17.72 \\
$3100-4000$ & 25 & 9.7 \\
\hline 4100 and above & 4 & 26.26 \\
\hline Total & $\mathbf{2 6 3}$ & $\mathbf{1 0 0}$ \\
\hline
\end{tabular}

Source: Authors computations

\section{B. Regression Results}

The coefficient of education was found to be statistically significant at $10 \%$ with probability of 0.084 as shown in Table VII. This implies that a unit addition to entrepreneur's level of education will raise his enterprise's income by $9.9 \%$. The positive relationship between education and entrepreneur's performance corroborates the evidence and align with [23], [21] and [20]. Similarly, the coefficient of the experience of the entrepreneur was found to be significant and positively related to the income of the enterprise (0.255). This conforms to apriori expectation. It implies that a unit increase in entrepreneurs experience on average tends to increase income of entrepreneurs by $25.5 \%$. This indicates that enterprises managed by experienced entrepreneurs are likely to generate higher income than those managed by inexperienced entrepreneurs.

Age has a positive coefficient of (0.112) which is in line with the apriori expectation that the older the entrepreneur the higher the performance of the enterprise he managed. It implies that a unit increase in entrepreneur's age on average tends to increase the income generation of the CMSSEs in the state by $11.2 \%$. Government support, a dummy variable has a positive coefficient of $(0.140)$ and is statistically significant at $5 \%$. This is in line with the apriori expectation that enterprises that receive government support are likely to performance better than those that did not receive any support.

The coefficient of size of enterprises is positive (0.010) but statistically insignificant. This implies that a unit increase in the size of enterprises on average tends to raise entrepreneurs income by $1 \%$ (Table VII). As anticipated the result shows the position of gender as a major determinant of income generation in the state with coefficient of (0.517). The coefficient of gender was found to be statistically significant at $1 \%$ with probability of (0.003). The result implies that male entrepreneurs on average generate income for the enterprise they manage better than their female counterparts by $51 \%$. The result is not surprising since the research area is predominantly Muslims that believe the responsibility of providing the daily needs of the family is on males not on females.

TABLE VII: REGRESSION RESULT OF THE DETERMINANTS OF INCOME OF CMSSES

\begin{tabular}{|c|c|c|c|c|}
\hline Variables & Coefficient & Std. Error & $\mathrm{T}$ & Sig. \\
\hline (Constant) & & 3567.486 & -1.632 & .104 \\
\hline Education & .099 & 366.487 & 2.735 & $.084 * * *$ \\
\hline Experience & .255 & 104.596 & 2.873 & $.004 *$ \\
\hline Age of entrepreneur & .112 & 71.142 & 1.273 & .204 \\
\hline Govt. Support & .140 & 1037.773 & 2.382 & $.018 * *$ \\
\hline Size of enterprise & .010 & 971.660 & .181 & .856 \\
\hline Sex of entrepreneur & .517 & 1112.252 & 2.961 & $.003^{*}$ \\
\hline Training & .036 & 854.401 & .631 & .528 \\
\hline Finance & .51 & 433.250 & 2.873 & $.007 *$ \\
\hline
\end{tabular}

$R^{2}=0.26, F=8.66$

Significance level at $1 \%(*) ; 5 \%(* *) ; 10 \%(* * *)$.

Source: Authors Computations

In line with our expectation the coefficient of skill (training) of the entrepreneur carried a positive sign and stood at 0.036. Although, statistically not significant to any level. This implies that a unit increase in entrepreneurial training on average tends to boost the entrepreneurs income by $3.6 \%$. The coefficient of finance is positive with a value 0.25 and statistically significant at $5 \%$ with probability value of 0.001 , which conforms to apriori anticipation. This means that, a unit increase in finance of entrepreneurs on average tends to increase the entrepreneurs income by $29 \%$. This is true because the higher the level of finance of an enterprise the higher the level of its income.

\section{CONCLUSION AND POLICY RECOMMENDATIONS}

The findings of the study revealed that CMSSEs are important tools for income generation in Jigawa state. The study employed primary sources of data where 300 questionnaires were administered to three local government areas of the state. The data was analyzed using descriptive statistics and multivariate regression analysis. The results obtained revealed that education, experience, government support, gender and finance are the key variables that determine income generation of CMSSEs in the state. Thus, this work is consistent with [20], [22], [23] on education. Also, it is in line with [9] on entrepreneurs' experience. But, [25] shows mix result as regard to government credit scheme on the profitability of firms can be positive or negative. This is contrary to our result that indicates positive relationship. On access to finance, [8] and [15] are consistent, while [27] contradict our finding, they observed negative relationship due to high interest rates in LDCs.

It is clear from the findings that CMSSEs in Jigawa state are important tools of income generation. Thus, the following policy recommendations are proffered: (1) In addition to the existing policy measures to provide CMSSEs access to finance, Deposit Money Banks (DMBs) and Micro Finance Banks (MFBs) should be mandated by the Central Bank of Nigeria to reserve some quota of their loanable funds for financing these enterprises. This will boost entrepreneurs' access to finance since most of them identified finance as their key business constraints; (2) Formation of trade, craft and 
professional associations, through which financial and other support services can be channeled to the CMSSEs to take care of collateral and repayment demands, should be encouraged; (3) The CMSSEs are suffering from unfair and unequal competition from foreign firms particularly China and other Asian firms. Therefore, government should initiate and enforce policies that will protect the small and vulnerable domestic businesses through quota restriction, licensing measures and tax instruments. The provision of the 1977 Indigenization Decree that preserved industries with low initial capital requirement exclusively for Nigerians, but which was later abrogated, should be brought back; and (4) Capacity building workshops should be organised on regular basis for the CMSSEs businesses with a view to training the operators financial management of these small enterprises.

APPENDIX

MODEL SUMMARY

\begin{tabular}{|c|c|c|c|c|}
\hline Model & $\mathrm{R}$ & R Square & Adjusted R Square & Std. Error of the Estimate \\
\hline 1 & $.506^{\mathrm{a}}$ & .256 & .226 & 7793.562 \\
\hline
\end{tabular}

\begin{tabular}{lcccccc}
\hline \multicolumn{7}{c}{} \\
\hline \multicolumn{1}{l}{ Model } & Sum of Squares & Df & Mean Square & F & Sig. \\
\hline 1 & Regression & $5.260 \mathrm{E} 9$ & 10 & $5.260 \mathrm{E} 8$ & 8.660 & $.000^{\mathrm{a}}$ \\
& Residual & $1.531 \mathrm{E} 10$ & 252 & $6.074 \mathrm{E} 7$ & & \\
& Total & $2.057 \mathrm{E} 10$ & 262 & & & \\
\hline
\end{tabular}

a. Predictors: (Constant), AGE, FIN, EDU, TYP, GND, SKL, GSP, EXP

b. Dependent Variable: INC

Coefficients $^{\text {a }}$

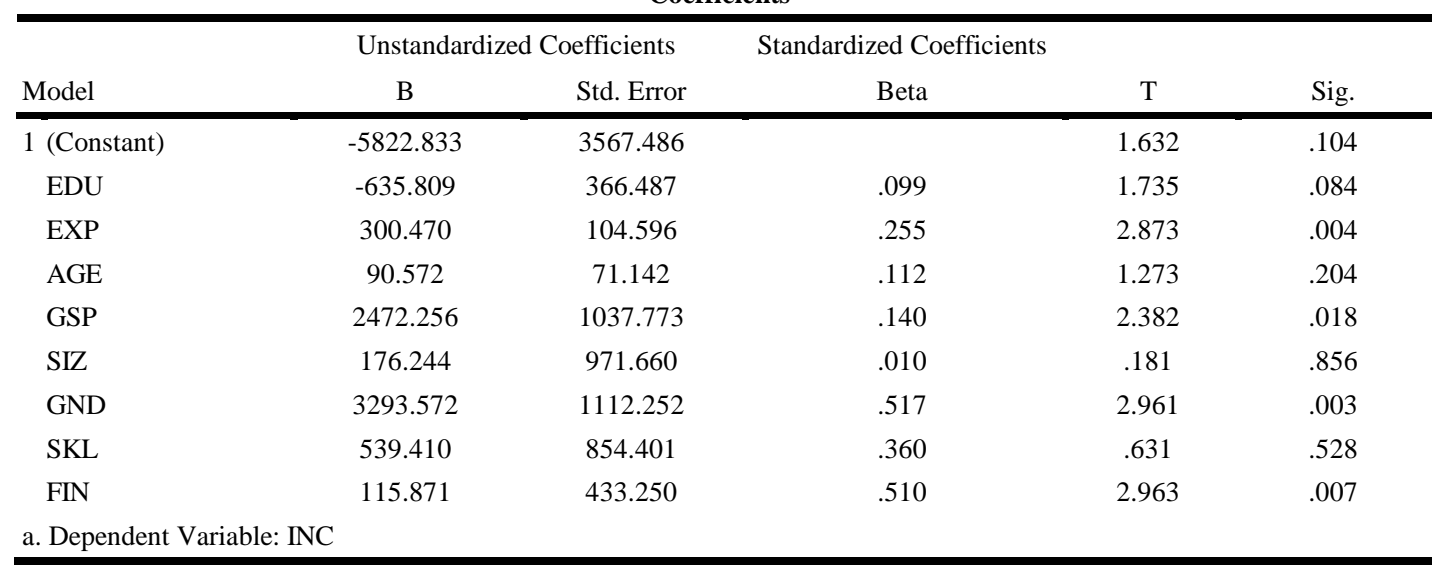

\section{ACKNOWLEDGMENT}

We would like to express our gratitude to Tetfund and Federal University Dutse for the financial support as well as to research assistants and all others who contributed to the successful execution of the study.

\section{REFERENCES}

[1] G. Nnanna, "The Importance of small and medium scale industries in Economic Development," presented at the Workshop on Small and Medium Scale Industries, Equity Investment Scheme, CBN, Abuja, Nigeria, 2002.

[2] S. E. Edusah, "The informal sector, micro-enterprises and small-scale industries: The conceptual quandary," Journal of Economics and Sustainable Development, vol. 4, no. 20, pp. 177-185, 2013.

[3] M. Y. Aremu and S. I. Adeyemi, "Small and medium scale enterprise as a strategy for employment generation in Nigeria," Journal of Sustainable Development, vol. 4, no. 1, February 2011.

[4] SMEDAN and NBS, Survey Report on Micro, Small and Medium Enterprises in Nigeria: Preliminary Report 2010, National MSMEs Collaborative Survey, 2010.

[5] Paths2. (2014). Paths2 Jigawa Quarter Twenty-Four Report. PATHS2 JG/5/QTR24/04. [Online]. Available: www.paths2.org/.../1422024870PATHS2.5

[6] Wikipedia. (2014). Jigawa state political economy. [Online]. Available: en.m. wikipedia.org/ wiki/Jigawa_State

[7] Informal sector represents $58 \%$ of Nigeria's GDP-UN, Daily Trust Newspaper, p. 23, June 25, 2014.
[8] R. N. Lussier, "A nonfinancial business success versus failure prediction model for young firms," Journal of Small Business Management, vol. 33, no. 1, pp. 8-20, 1995.

[9] P. Reynolds, N. Carter, and M. Williams, "Discontinuance among new firms in retail: the influence of initial resources, Strategy and gender," Journal of Business Venturing, vol. 12, no. 2, pp. 125-145, 1997.

[10] W. Bonte, O. Falak, and S. Heblick, "The impact of regional age structure in entrepreneurship," Journal of Economic Geography, vol. 85 , no. 3, pp. 269-289, 2009.

[11] H. Wijewardena and G. E. Tibbits, "Factors contributing to the growth of small manufacturing firms: Data from Australia," Journal of Small Business Management, vol. 37, no. 2, pp.88-95, 1999.

[12] T. Blackwood and G. Mowl, "Expatriate-owned small businesses: Measuring and accounting for success," International Small Business Journal, vol.18, no.3, pp. 60-73, 2000.

[13] M. Hashim and S. Ahmad, "An assessment of training practices among Malaysian SMEs," Advances in Global Business Research, vol. 3, no. $1,2006$.

[14] J. Jones, "Training, development, and business growth: A study of Australian manufacturing small-medium sized enterprises," Asia Pacific Journal of Human Resources, vol. 42, no. 1, pp. 96-121, 2004.

[15] R. O. Akingunola, "Small and medium scale enterprises and economic growth in Nigeria: An assessment of financing options," Pakistan Journal of Business and Economic Review, vol. 2, no. 1, pp. 78-97, 2011.

[16] S. Kristiansen, B. Furuholt, and F. Wahid, "Internet cafe entrepreneurs: Pioneers in information dissemination in Indonesia," The International Journal of Entrepreneurship and Innovation, vol. 4, no. 4, pp. 251-263, 2003. 
[17] H. Wijewardena and S. Cooray, "Determinant of growth in small japanese manufacturing firms: Survey evidence from Kobe," Journal of Small Business Management, vol. 3, no. 4, pp. 87-92, 1995.

[18] M. Binks and T. Ennew, "Financing small firms," in Small Business and Entrepreneurship, P. Burns and J. Dewhurst, Eds. McMillan, London, 1996.

[19] B. Ruth. (2011). Developing a supply chain performance tool for SMEs in Thailand. Supply Chain Management: An International Journal. [Online]. 16(1). pp. 20-31. Available: http://www.emeraldinsight.com/1359-8546.htm

[20] K. King and S. McGrath, "Globalisation, enterprise and knowledge: educational training and development," International Review of Education, vol. 50, no. 1, pp. 74-76, 2002.

[21] A. Charney and G. D. Libecap, Impact of Entrepreneurship Education, Kauffman Center for Entrepreneurial Leadership, 2000.

[22] T. N. Sinha, "Human factors in entrepreneurship effectiveness," The Journal of Entrepreneurship, vol. 5, no. 1, pp. 23-39, 1996.

[23] L. A. Meng and T. W. Liang, Entrepreneurs, Entrepreneurship and Enterprising Culture, Paris: Addison-Wesley, 1996.

[24] T. Noe, "Effects of strategic human resource management practices on perceived financial performance: Some evidence from the Nigerian financial sector," International Journal of Management Science, vol. 1, no. 2, pp. 29-35, 1998.

[25] C. Correia, O. Flynn, E. Ulinua, and M. Wormaid, Financial Management, 6th ed. Jutter and Company Limited: Cape Town, 2003.

[26] A. Maseco, F. Holmes, P. Hulchincon, and D. Forsath, Small Enterprise Financing Management: Theory and Practice, Harcourt, Brace Publishers: Sydney, 1993.

[27] N. Michaelas, F. Cluttenden, and F. Pootziouris, "Financing policy and capital structure choice by the UK SMEs: Empirical evidence from company panel data," Small Bus. Econ., vol. 12, no. 2, pp. 113-130, 1999.

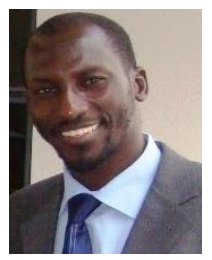

Bello Malam Sa'idu was born in Hashidu, Gombe state on March 1, 1970. He is currently an assistant professor (senior lecturer) at the Department of Economics \& Development Studies, Federal University Dutse, Jigawa state of Nigeria. He obtained the doctor of philosophy degree (Ph.D. economics) in 2010 from Universiti Utara Malaysia, M.Sc. degree in economics from Bayero University Kano in 2004 and B.Sc. (Honours) degree in economics from University of Maiduguri in 1994. He is a fellow of Institute of Debt Recovery Practitioners of Nigeria (IDRPN) and Member, Conference Master International Malaysia.

Dr. Bello has published extensively in peer-reviewed journals and conference proceedings. He has presented papers in conferences and his articles have appeared in national and international journals such as European Scientific Journal, European Journal of Social Sciences, International Journal of Development Studies, Global Journal of Socia Sciences. Also, his book titled "Poverty, income inequality and millennium development goals in Nigeria: New perspectives and current issues" was published on September 27, 2011 by LAP LAMBERT Academic Publishing, Germany. His fields of expertise include economic development and planning, economic theory, applied econometrics and international financial development.

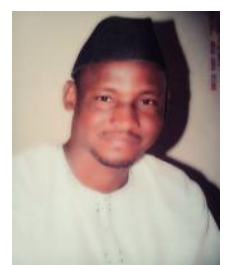

Muhammad Muazu Yusuf was born in Sokoto the capital city of Sokoto state of Nigeria on January 6, 1968. He attended Usmanu Danfodiyo University Sokoto for his bachelor degree, master degree and $\mathrm{Ph} . \mathrm{D}$ degree in economics. He is currently a lecturer with Federal university Dutse, Jigawa state Nigeria.

Ibrahim Muhammad Adam was born in Nassarawa of Kano state on June 27, 1975. He obtained the B.Sc. (Honours) and M.Sc. degrees in economics at the Bayero University Kano of Nigeria in 1996 and 2003 respectively. Also, he got the MBA degree from the same University in 2008. His major field of specialization is monetary economics. Mr. Ibrahim is a lecturer and PG coordinator in the Department of Economics and Development Studies, Federal University Dutse, Jigawa state of Nigeria. He was a training instructor in First Bank of Nigeria PLC from 2005 to 2012 and a former lecturer at the Kano State Polytechnic from 1997 to 1999 and coordinator of HND Banking \& Finance. His areas of research interest are monetary economics, banking and finance, entrepreneurship and environmental economics. 